\title{
Computer-Based Pharmacognosy: A Review
}

\section{Mostafa NM and Singab ANB*}

Department of Pharmacognosy, Faculty of Pharmacy, Ain Shams University, Egypt

*Corresponding author: Professor of Pharmacognosy, Vice President for Graduate Studies and Research, Chairman of Center for Drug Discovery and Development Research, Faculty of Pharmacy, Ain Shams University, 11566, Cairo, Egypt, Tel: +2 0224051120 ; Email: dean@pharma.asu.edu.eg

\section{Abstract}

In search of modern ways to increase secondary metabolites production in plants, implement genetic engineering, and produce green pollution-free medicinal plants, modern computer-based techniques must be regarded. The introduction of Computer Aided Drug Discovery (CADD), in particular in-silico molecular modeling protocols have become indispensable for the study of macromolecular structures and interactions. In addition, the application of chemometric techniques allowed the analysis of multivariate data. Molecular pharmacognosy has been also introduced to carry the traditional pharmacognosy mission into a molecular level.

Keywords: CADD; Molecular pharmacognosy; Chemometry; Computer based techniques

Abbreviations: CADD: Computer Aided Drug Discovery; QSAR: Quantitative Structure-Activity Relationship; CDK2: Cyclin-Dependent Kinase 2; PCA: Principal Component Analysis; ICS: International Chemometrics Society.

\section{Introduction}

The scientific significance of phytotherapy has elevated nowadays, being defined as the use of naturallyoriginated extracts and its applicability in medical purposes. Yet, more attention has to be drawn on the safety, quality control and effectiveness of the used medicinal plants [1]. WHO published numerous recommendations and monographs [2-5] on the cultivation, efficacy and quality control procedures for selected medicinal plants that are considered essential parts of complementary and alternative medicines to be used instead or along with some well-established systems for health-care [6].
Pharmacognosy is a developing science that started by dealing with morphology and taxonomy of crude drugs, then it focused on isolation, quantification and structure elucidation of active compounds [7-9], these phytochemicals may have potential protective or disease preventive properties [10,11], essential oils characterization [12-14], and recently the term Reverse Pharmacognosy has evolved by concerning with the potential biological activity of a crude drug or its isolated compounds. This can result in the discovery of novel lead compounds or new biological activities $[7,15]$.

In the current review, we present herein some selected approaches of computer-based techniques that are widely used and applied nowadays to develop advanced phyto-therapeutic applications.

\section{Computer-Aided Drug Discovery}

Computer Aided Drug Discovery (CADD) forms the basis of Reverse Pharmacognosy, in which already 


\section{Open Access Journal of Pharmaceutical Research}

isolated lead compounds are searched in commercial databases, and then structure determination of target enzyme is performed by experimental methods, followed by design of inhibitor molecules [16]. There are two approaches for the virtual screening, the first is screening based on ligand properties, such as physicochemical properties and pharmacophores (3D data) which are techniques of quantitative structure-activity relationship (QSAR). The second approach is docking and in silico molecular modeling, which are performed by a variety of softwares [17].

\section{Docking Studies}

Docking studies have become indispensable for the study of macromolecular structures and interactions. Mechanical model construction requires heroic patience and endurance to complete a structure which may contain thousands of atoms while computer graphics can build and display in seconds [18]. Macromolecular modelling by docking studies provides detailed possible view of drugreceptor interaction and has created a new rational approach to drug design. The structure of drug is designed based on its fit to 3D-structures of receptor site, rather than by analogy to other active structures or random leads $[18,19]$.

An example of the application of in silico molecular modeling in pharmacognosy, is the isolation of a novel biflavonoid [kaempferol ( $6 \rightarrow 8$ ") apigenin] from the leaves of Jacaranda acutifolia. The compound showed promising cytotoxic activity against breast cancer cell line MCF-7 $(\mathrm{IC} 50=18.3 \mu \mathrm{g} / \mathrm{mL})$. The anticancer activity was explained via virtual docking of the isolated compound to the main sites in the human cyclin-dependent kinase 2 (CDK2) crystal structure [19].

\section{Chemometric Techniques}

Another computer-based technology is the application of chemometric techniques. In fact, chemometry provides a good opportunity for mining chemical information from the original data. Comprehensive methods and hyphenated techniques associated with chemometrics, used for extracting information and supplying various methods of data processing, are used in medicinal plants. Principal Component Analysis (PCA) is the most commonly used technique. It is usually used for handling the multivariate data without prior knowledge about studied samples [20].
Chemometrics is the application of both mathematical and statistical techniques in order to retrieve more information from different chromatographic data. The International Chemometrics Society (ICS) defines chemometrics as the science of relating measurements made on a chemical system or process to the state of the system via application of mathematical or statistical methods. Chemometrics methods become a leading tool towards faster analysis results and shorter product development time [21].

There are various techniques that are used for this sort of determination such as HPLC, UHPLC, GC, TLC and FTIR. Moreover, hyphenated chromatography and spectroscopy like HPLC-DAD, GC-MS, CE-DAD, HPLC-MS and HPLC-NMR might give the additional spectral information which may be helpful for the qualitative and quantitative analysis [20].

\section{Molecular Pharmacognosy}

At the boundary between pharmacognosy and molecular biology, molecular pharmacognosy has developed as a new borderline discipline. It is a science dealing with the study of identification, classification, cultivation, protection of crude drugs, and production of effective element at a molecular level. This means that it carries the traditional mission of pharmacognosy, endows it with new tasks, challenges and deals with crude drugs at genetic level based on gene-molecular biology [22].

Techniques of molecular biology applied to pharmacognosy are various, of which, Random Amplified Polymorphic DNA (RAPD) analysis technique for plant genetic study, molecular markers, recombinant DNA, gene chip technique which is used for gene expression profiles and construction of genomic library, biotransformation and elicitors that stimulate plant defense and used to increase secondary metabolites production [23]. One of the main goals to achieve in molecular pharmacognosy is implementing genetic engineering, advocating green pollution-free medicinal plants, and controlling pesticides without farm chemical in the process of growing medicinal plants. Molecular pharmacognosy is concerned also with the gene regulation of metabolic pathway, as an attempt to improve the active constituents' content, and the quality of herbal drugs [24].

\section{Conclusion}

The ultimate goal of this review is to highlight the role of computer-based technologies in the advance of 


\section{Open Access Journal of Pharmaceutical Research}

pharmacognosy, the development of the term of reverse pharmacognosy with the aid of computer aided drug design and in silico molecular modeling. New quality control terms through chemometrics by relating chromatographic measurements to statistical data, and new term of molecular pharmacognosy by introducing molecular biology techniques. Thus, pharmacognosy becomes more and more a developing science to help progress in all fields of life.

\section{References}

1. Ghosh D (2016) Seed to patient in clinically proven natural medicines. Nutraceuticals Pp: 925-931.

2. WHO (1999) Monographs on selected medicinal plants. World Health Organization Geneva 1: 1-295.

3. WHO (2004) Monographs on selected medicinal plants. World Health Organization 2: 1-357.

4. WHO (2007) Monographs on selected medicinal plants. World Health Organization Geneva 3: 1-390.

5. WHO (2009) Monographs on selected medicinal plants. World Health Organization Geneva 4: 1-456.

6. Heinrich M, Barnes J, Gibbons S, Williamson EM (2012) Fundamentals of pharmacognosy and phytotherapy. $2^{\text {nd }}($ Edn.), Churchill Livingstone, Elsevier Pp: 1-337.

7. Bohlin L, Göransson U, Alsmark C, Wedén C, Backlund A (2010) Natural products in modern life science. Phytochem Rev 9(2): 279-301.

8. Singab AN, Ayoub NA, Ali EN, Mostafa NM (2010) Antioxidant and hepatoprotective activities of Egyptian Moraceous plants against carbon tetrachloride-induced oxidative stress and liver damage in rats. Pharm Biol 48(11): 1255-1264.

9. Mostafa NM (2017) Comparative analysis of rutin content in some Egyptian plants: A validated RPHPLC-DAD approach. European J Med Plants 19(2): 18.

10. Mostafa NM, Eldahshan OA, Singab AB (2013) Pyrostegia venusta (Ker Gawl.) Miers: A botanical, pharmacological and phytochemical review. Med Aromat Plants 2(3): 123.

11. Mostafa NM, Eldahshan OA, Singab AB (2014) The genus Jacaranda (Bignoniaceae): an updated review. Phcog Commn 4(3): 31-39.

12. Ayoub N, Singab AN, Mostafa N, Schultze W (2010) Volatile constituents of leaves of Ficus carica Linn. Grown in Egypt. J Essent Oil Bear Pl 13(3): 316-321.
13. Mostafa NM, Eldahshan OA, Singab AB (2015) Chemical composition and antimicrobial activity of flower essential oil of Jacaranda acutifolia Juss. against food-borne pathogens. European J Med Plants 6(2): 62-69.

14. Singab AB, Mostafa NM, Eldahshan OA, Ashour ML, Wink M (2014) Profile of volatile components of hydrodistilled and extracted leaves of Jacaranda acutifolia and their antimicrobial activity against foodborne pathogens. Nat Prod Commun 9(7): 10071010.

15. Mostafa NM, Singab AB (2016) After HCV eradication with Sovaldi ${ }^{\circledR}$, can herbs regenerate damaged liver, minimize side effects and reduce the bill? Med Aromat Plants 5(4): 1-4.

16. Medina-Franco JL (2013) Advances in computational approaches for drug discovery based on natural products. Rev latinoam quim 41(2): 95-110.

17. Sliwoski G, Kothiwale S, Meiler J, Lowe ED (2014) Computational methods in drug discovery. Pharmacol Rev 66(1): 334-395.

18. Bothara KG, Patil AU, Sexena A (1998) Importance of docking studies in drug design. Indian J Pharm Sci 60(6): 333-337.

19. Mostafa NM, Ashour ML, Eldahshan OA, Singab AN (2015) Cytotoxic activity and molecular docking of a novel biflavonoid isolated from Jacaranda acutifolia (Bignoniaceae). Nat Prod Res 30(18): 2093-2100.

20. Bansal A, Chhabra V, Rawal RK, Sharma S (2014) Chemometrics: A new scenario in herbal drug standardization. Journal of Pharmaceutical Analysis 4(4): 223-233.

21. Tyszkiewicz J, Tyszkiewicz S (2004) An introduction to chemometrics for food science. Pol J Food Nutr Sci 13: 75-86.

22. Huang LQ (2012) Molecular Pharmacognosy. Springer, New York, USA.

23. Soni H, Narwani P, Singhai AK (2015) A new era of pharmacognosy-"Molecular Pharmacognosy". MIT Int J Pharm Sci 1(1): 64-70.

24. Singab AN, Mostafa NM (2016) Molecular Pharmacognosy: A Promising and Prospective Scope in the Field. Med Aromat Plants 5(2): 1-2.

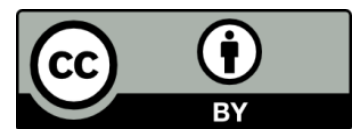

Copyright(C) Mostafa NM and Singab ANB. 